\title{
MITIGASI BENCANA BERBASIS KEARIFAN LOKAL MASYARAKAT BADUY
}

\author{
Suparmini, Sriadi Setyawati, Dyah Respati Suryo Sumunar \\ FIS Universitas Negeri Yogyakarta \\ email: suparmini@uny.ac.id
}

\begin{abstract}
Abstrak: Mitigasi Bencana Berbasis Kearifan Lokal Masyarakat Baduy. Penelitian ini bertujuan untuk mengetahui (1) kearifan lokal masyarakat Baduy yang tinggal di Desa Kanekes, Kecamatan Leuwidamar, Kabupaten Lebak Provinsi Banten, dan (2) kearifan lokal yang berkaitan dengan mitigasi bencana alam gempa bumi, banjir, tanah longsor, dan kebakaran. Penelitian ini menggunakan metode deskriptif kualitatif. Pengumpulan data dilakukan melalui observasi, dokumentasi, dan wawancara. Analisis data secara kualitatif, melalui reduksi data, penyajian data, hingga pengambilan kesimpulan. Hasil penelitian menunjukkan bahwa masyarakat Baduy, tetap memegang kuat kepercayaan dan adat istiadatnya serta meniti hari demi hari dengan penuh kearifan. Kepercayaan dan adat istiadat itu menjadi pikukuh (aturan) yang senantiasa menjadi falsafah hidup dan keseharian masyarakat Baduy. Kearifan lokal masyarakat Baduy berkaitan dengan mitigasi bencana gempa bumi, tanah longsor, banjir, dan kebakaran tercermin dalam (1) tradisi perladangan, yakni dengan aturan pemilihan lokasi ladang (huma), waktu berladang, tata cara membuka dan membakar lahan, hingga peralatan yang diperbolehkan untuk digunakan. Tradisi perladangan menghindarkan dari bahaya longsor, dan kebakaran. (2) Aturan dan pikukuh dalam membuat bangun bangunan rumah, jembatan, lumbung, dan sebagainya dengan bahan bambu, ijuk, dan kirey tanpa paku. Bangunan didirikan di atas tanah menyesuaikan kontur tanah, didirikan di atas umpak, tidak diperbolehkan mengubah kontur tanah. Hal itu merupakan mitigasi terhadap bencana gempa, longsor, banjir, dan kebakaran. (3) Pembagian zona hutan dalam tiga wilayah sebagai wujud nyata pelestarian ekosistem dan merupakan mitigasi terhadap bencana longsor, banjir, erosi, dan bencana lainnya.
\end{abstract}

Kata kunci: mitigasi bencana, masyarakat Baduy, kearifan lokal

Abstract: Disaster Mitigation Based Local Wisdom Baduy Community. This study aims to know (1) indigenous Baduy community who live in the Kanekes village, Leuwidamar sub district, Lebak Banten, and (2) local knowledge relating to the mitigation of natural disasters as earthquakes, floods, landslides, and fire. This study used a qualitative descriptive method. Data was collected by observation, documentation, and interviews. Data were analyzed qualitatively, through data reduction, data presentation, to a conclusion. The results showed that Baduy community, still hold strong beliefs and customs as well as day by day with great wisdom. Beliefs and customs that become pikukuh (rules) which has always been the philosophy of life and daily Baduy. Local knowledge related to mitigation Baduy earthquakes, landslides, floods, and fires reflected in (1) farming tradition, namely the rules of the site selection fields (huma), time farming, and open burning ordinances lands, until equipment is allowed for use. Cultivation tradition of avoiding the danger of landslides, and fires. (2) Rules and pikukuh in making the wake of houses, bridges, barns, and so forth with bamboo materials, fibers, and Kirey without nails. Buildings erected on the land contour adjust, founded on pedestals, are not allowed to changed the contour of the land. It was a mitigation 
of the earthquake, landslides, floods, and fires. (3) The division of the forest zone in the three regions as a tangible manifestation of the conservation of ecosystems and a mitigation of the landslide, flooding, erosion, and other disasters.

Keywords: disaster mitigation, Baduy, local wisdom

\section{PENDAHULUAN}

Masyarakat Baduy berada di Desa Kanekes, Kecamatan Leuwidamar, Kabupaten Lebak Provinsi Banten merupakan salah satu suku di Indonesia yang sampai sekarang masih mempertahankan nilainilai budaya dasar yang dimiliki dan diyakininya, di tengah-tengah kemajuan peradaban di sekitarnya. Wilayah Kanekes secara geografis terletak pada koordinat $6^{\circ} 27^{\prime} 27^{\prime \prime}-6^{\circ} 30^{\prime} 0^{\prime \prime}$ LS dan 108 $3^{\prime} 9^{\prime \prime}$ $106^{\circ} 4^{\prime} 55^{\prime \prime} \mathrm{BT}$, ditinggali oleh masyarakat (suku) Baduy secara turun temurun hingga sekarang. Wilayah yang merupakan bagian dari Pegunungan Keundeng dengan ketinggian 300-600m di atas permukaan laut (dpl) tersebut mempunyai topografi berbukit dan bergelombang dengan kemiringan tanah rata-rata mencapai $45 \%$, yang merupakan tanah vulkanik (di bagian utara), tanah endapan (di bagian tengah), dan tanah campuran (di bagian selatan) suhu rata-rata $20^{\circ} \mathrm{C}$.

Masyarakat Baduy mendiami kawasan Pegunungan Keundeng, memiliki tanah adat kurang lebih sekitar 5.108hektar, mereka memiliki prinsip hidup cinta damai, tidak mau berkonflik dan taat pada tradisi lama mereka, serta hukum adat, dan tentu saja memiliki kearifan lokal tradisional sendiri yang dianggap unik dan menarik bagi orang luar Baduy. Masyarakat Baduy secara umum telah memiliki konsep dan mempraktekkan pencagaran alam (nature conservation). Misalnya mereka sangat memperhatikan keselamatan hutan. Hal ini mereka lakukan karena mereka sangat menyadari bahwa dengan menjaga hutan maka akan menjaga keterlanjutan ladangnya juga. Lahan hutan yang berada di luar wilayah permukiman, biasa mereka buka setiap tahun secara bergilir untuk dijadikan lahan ladang (Suparmini, dkk, 2012:53)

Masyarakat Baduy merupakan masyarakat tradisional bersahaja dan kaya sumber kearifan yang dapat menjadi teladan dan panutan kita. Hingga saat ini masyarakat Baduy masih terikat pada pikukuh (adat yang kuat) yang diturunkan dari generasi ke generasi. Salah satu pikukuh itu berbunyi lojor teu meunang dipotong, pondok teu meunang disambungan, yang berarti panjang tidak boleh dipotong, pendek tidak boleh disambung. Makna pikukuh itu antar lain tidak mengubah sesuatu, atau dapat juga berarti menerima apa yang sudah ada. Insan Baduy yang melanggar pikukuh akan memperoleh ganjaran adat dari puun (pimpinan adat tertinggi).

Masyarakat Baduy yang tinggal di Desa Kanekes, Kecamatan Leuwidamar, Kabupaten Lebak merupakan daerah yang tidakluput dari bencana, terutama bencana alam. Sejalan dengan perkembangan waktu, masyarakat umumnya memiliki pengetahuan dan kearifan dalam memprediksi dan melakukan mitigasi bencana di wilayahnya. Pengetahuan dan teknologi lokal biasanya diperoleh dati pengalaman empiris yang kaya akibat dari interaksi dengan lingkungannya. Hal itupun terjadi pada masyarakat Baduy, dimana mereka memiliki cara-cara tertentu untuk melakukan mitigasi terhadap bencana yang potensial terjadi di wilayahnya.

Secara umum, mitigasi bencana diartikan sebagai sebuah upaya perencanaan yang tepat untuk meminimalisir dampak negatif bencana terhadap manusia. Mitigasi bencana merupakan salah satu dari kegiatan manajemen bencana, yang meliputi: (1) kegiatan prabencana, 
yakni kegiatan pencegahan, mitigasi, kesiapsiagaan, serta peringatan dini; (2) kegiatan saat terjadi bencana, meliputi kegiatan tanggap darurat, kegiatan SAR (search and resque), bantuan darurat, dan pengungsian, serta (3) kegiatan pascabencana yang mencakup kegiatan pemilihan, rehabilitasi, dan rekonstruksi. (UU No 24 Tahun 2007).

Penelitian ini mencoba mengkaji tentang kearifan lokal tradisional masyarakat Baduy yang berkaitan dengan mitigasi bencana, khususnya, gempa bumi, banjir, tanah longsor, dan kebakaran.

Kearifan atau wisdom merupakan suatu pemahaman kolektif, pengetahun, dan kebijaksanaan yang mempengaruhi keputusan penyelesaian atau penanggulangan suatu masalah kehidupan. Kearifan dalam hal ini merupakan perwujudan seperangkat pemahaman dan pengetahuan yang mengalami proses perkembangan oleh suatu kelompok masyarakat setempat atau komunitas yang terhimpun dari proses dan pengalaman panjang dalam berinteraksi dalam satu sistem dan dalam satu ikatan hubungan yang saling menguntungkan (Purba, 2002 dalam Marfai, 2012:33). Indonesia memiliki banyak etnik dan suku bangsa, dimana setiap etnik dan suku bangsa mempunyai sistem dan pendekatannya sendiri dalam memahami dan bersikap terhadap pengelolaan sumberdaya alam. Hampir setiap suku atau kelompok etnis mempunyai sistem pengetahuan tradisional tersendiri bahkan telah melahirkan inovasi pengelolaan lingkungan dan pemanfaatan sumberdaya alam yang unik berbasis adat dan budaya setempat.

Menurut Sartini (2009:11), kearifan lokal disimpulkan sebagai kepribadian, identitas kultural masyarakat yang berupa nilai, norma, etika, kepercayaan, adat istiadat, dan aturan khusus yang diterima oleh masyarakatnya dan teruji kemampuannya sehingga dapat bertahan secara terus menerus. Kearifan lokal pada prinsipnya bernilai baik dan merupakan keunggulan budaya masyarakat setempat yang berkaitan dengan kondisi geografis secara luas.

Kearifan lokal juga dapat diartikan sebagai pandangan hidup dan pengetahuan serta berbagai strategi kehidupan yang berwujud aktivitas yang dilakukan oleh masyarakat lokal dalam menjawab berbagai masalah dalam pemenuhan kebutuhan mereka, meliputi seluruh unsur kehidupan; agama, ilmu penetahuan, ekonomi, teknologi, organisasi sosial, bahasa dan komunikasi, serta kesenian. Mereka mempunyai pemahaman, program, kegiatan, pelaksanaan terkait untuk mempertahankan, memperbaiki, dan mengembangkan unsur kebutuhan dan cara pemenuhannya, dengan mem-perhatikan sumber daya manusia dan sumber daya alam di sekitarnya.

Kearifan lokal dipandang sangat bernilai dan mempunyai manfaat tersendiri dalam kehidupan masyarakat. Sistem tersebut dikembangkan karena adanya kebutuhan untuk menghayati, mempertahankan, dan melangsungkan hidup sesuai dengan situasi, kondisi, kemampuan, dan tata nilai yang dihayati di dalam masyarakat yang bersangkutan. Dengan kata lain, kearifan lokal tersebut kemudian menjadi bagian dari cara hidup mereka yang arif untuk memecahkan segala permasalahan hidup yang mereka hadapi. Berkat kearifan lokal mereka dapat melangsungkan kehidupannya, bahkan dapat berkembang secara berkelanjutan (sustainable development) (Permana, 2010: 3).

Dalam keseharian, terdapat berbagai pandangan dan pendapat tentang bencana yang tumbuh dan berkembang dalam masyarakat. Pandangan dan pendapat tersebut sesuai dengan tingkat pendidikan dan pemahaman personal atau kelompok tentang bencana. Beberapa pandangan dan pendapat masyarakat tentang bencana adalah sebagai berikut.

Fatalisme, yakni pandangan yang menganggap bahwa bencana merupakan 
kutukan atau murka Tuhan akibat ulah manusia yang tidak sesuai dengan kehendak-Nya. Dengan demikian kejadian bencana tidak dapat ditanggulangi tau dilawan karena smua adalah suratan takdir.

Anthroposentrisme, adalah pandangan yang beranggapan bahwa bencana merupakan fenomena alam yang disebabkan oleh ulah manusia yang mengesploitasi alam sedemikian rupa sehingga menyebabkan terjadinya ketidakseimbangan unsur semesta, yang pada akhirnya menimbulkan bencana.

Kosmosentrisme, suatu pandangan yang beranggapan bahwa bencana merupakan fenomena alam yang terjadi secara alamiah, sesuatu yang wajar terjadi. Jika memang telah tiba saatnya, alam berobah menyesuaikan komposisi alamiahnya. Dalam hal ini campur tangan manusia untuk mengesploitasi alam tidak terlalu signifikan mempengaruhi terjadinya bencana.

Inklusivisme, yakni pandangan yang beranggapan bahwa bencana merupakan fenomena alam yang terjadi karena keterkaitan antara unsur alam dan manusia yang tidak terpisahkan satu sama lain. (Priambodo, 2009:21).

Menurut Undang-undang Nomor 24 Tahun 2007, bencana dapat didefinisikan sebagai peristiwa atau rangkaian peristiwa yang mengancam dan mengganggu kehidupan dan penghidupan masyarakat yang disebabkan, baik oleh faktor alam dan/atau faktor nonalam maupun faktor manusia sehingga mengakibatkan timbulnya korban jiwa manusia, kerusakan lingkungan, kerugian harta benda, dan dampak psikologis.

Berdasarkan sumber dan penyebabnya, bencana dapat dikelompokkan menjadi: (a)Bencana alam adalah segala jenis bencana yang sumber, perilaku, dan faktor penyebab atau pengaruhnya berasal dari alam, seperti: banjir, tanah longsor, gempabumi, erupsigunungapi, kekeringan, angin ribut dan tsunami. (b) Bencana nonalam adalah adalah bencana yang diakibatkan oleh peristiwa atau rangkaian peristiwa nonalam yang antara lain berupa gagal teknologi, gagal modernisasi, epidemi, dan wabah penyakit. (c) Bencana sosial, adalah bencana yang diakibatkan oleh peristiwa atau serangkaian peristiwa yang diakibatkan oleh manusia yang meliputi konflik sosial antarkelompok atau antarkomunitas masyarakat, dan teror.

Penanggulangan bencana merupakan serangkaian upaya yang meliputi pe-netapan kebijakan pembangunan yang berisiko timbulnya bencana, kegiatan pencegahan bencana, tanggap darurat, dan rehabilitasi. Tujuan dari penanggulangan bencana adalah (a) memberikan perlindungan kepada masyarakat dari ancaman bencana; (b) menyelaraskan peraturan perundangundangan yang sudah ada; (c) menjamin terselenggaranya penanggulangan bencana secara terencana, terpadu, terkoordinasi, dan menyeluruh; (d) menghargai budaya lokal; (e) membangun partisipasi dan kemitraan publik serta swasta; (f) mendorong semangat gotong royong, kesetiakawanan, dan kedermawanan; dan (g) menciptakan perdamaian dalam kehidupan bermasyarakat, berbangsa, dan bernegara. Penyelenggaraan penanggulangan bencana terdiri atas 3 (tiga) tahap meliputi: (a) prabencana; (b) saat tanggap darurat; dan (c) pascabencana.

Masyarakattradisional padaumumnya telah lama hidup berdampingan dengan alam secara harmonis, sehingga mengenal berbagai cara memanfaatkan sumberdaya alam secara berkelanjutan. Dalam kearifan lingkungan juga terwujud konservasi yang dilakukan oleh masyarakat.

Kearifan lokal yang diwujudkan dalam bentuk perilaku adaptif terhadap lingkungan mempunyai peranan penting dalam pengurangan resiko bencana. 
Kearifan lokal yang berlaku di suatu masyarakat memberikan dampak positif bagi masyarakat dalam menghadapi dan mensikapi bencana yang datang. Kearifan lokal merupakan ekstraksi dari berbagai pengalaman yang bersifat turun temurun dari nenek moyang atau orang-orang terdahulu yang telah mengalami kejadian bencana (Marfai, 2012:50).

Menurut Marfai dan Khasanah (2008) dalam Marfai (2012:52), adaptasi yang dilakukan manusia terhadap lingkungannya termasuk di dalamnya lingkungan fisik dan proses alam seperti terjadinya bencana menunjukkan adanya interelasi antara manusia dan lingkungan. Dalam hubungan yang saling terkait ini perubahan pada suatu komponen akan menyebabkan perubahan lain dan sebaliknya. Dalam konteks ini pendekatan human ecology menekankan atau menunjukkan adanya hubungan saling terkait (interplay) antara lingkungan dan proses-proses fisik yang berlangsung di dalamnya dan sistem-sistem sosial/ budaya. Dalam proses interaksinya dengan lingkungan sekitar kemudian tercipta budaya dan kearifan lokal.

Kemampuan adaptasi dapat diilustrasikan dalam bentuk setting budaya yang tidak mudah mengalami perubahan dan pergeseran tanpa adanya transisi kultural yang dalam hal ini memerlukan waktu yang lama. Selain dipengaruhi oleh karakteristik masyarakat, kemampuan adaptasi juga dipengaruhi oleh keberadaan dan ancaman bencana dan ketersediaan sumber daya lokal. Kemampuan masyarakat dalam melakukan mitigasi bencana tidak terlepas dari kajian-kajian terhadap budaya dan kearifan lokal serta kemampuan adaptasi masyarakat. Adaptasi adalah suatu strategi penyesuaian diri yang digunakan manusia selama hidupnya untuk merespon terhadap perubahan lingkungan dan sosial (Marfai, 2012:53).

Kearifan lokal masyarakat Baduy dalam upaya konservasi dan pelestarian lingkunganakan mencakup tiga unsur,yaitu sosial (harmonis), ekonomi (profitable), dan ekologi (lestari). Ketiga aspek dalam pengelolaan dan pelestarian lingkungan yang berkelanjutan tersebut menunjukkan kesaling-hubungan satu sama lain. Kearifan lokal berupa pengetahuan, keyakinan, pemahaman, wawasan, serta adat kebiasaan atau etika yang menuntun perilaku manusia dalam kehidupan sangat terkait dengan kondisi wilayah dan komunitas yang diwariskan secara turun temurun, sehingga bentuk kearifan lokal dapat dilihat melalui pendekatan kultural, yang terdiri dari pengetahuan lokal, budaya lokal, keterampilan lokal, sumber lokal, dan proses sosial lokal. Kearifan lokal masyarakat Baduy tercermin pula dalam kaitannya dengan upaya mitigasi bencana. Atau dengan kata lain, pengetahuan dan kearifan lokal dalam mitigasi bencana dapat digali dari dokumentasi bentuk aktivitas masyarakat Baduy yang meliputi antara lain aktivitas tebang-bakar lahan, bentuk dan struktur dan tata letak bangun bangunan, pengelolaan dan pemanfaatan sumber air, hutan, dan gunung.

\section{METODE}

Penelitian ini didesain sebagai penelitian deskriptif kualitatif, dimana hasil dari penelitian ini berusaha untuk menjelaskan secara rinci mengenai keadaan yang ada di lapangan. Dalam penelitian kualitatif, teori dan sumber data dapat berkembang di lapangan.

Dalam penelitian ini, variabel yang diamati adalah (a) Alam dan lingkungan masyarakat Baduy; (b) Kearifan lokal masyarakat Baduy; (c) Pola mitigasi bencana masyarakat Baduy. Penduduk Kampung (Masyarakat) Baduy pada umumnya menjadi subjek dalam penelitian ini. Beberapa narasumber atau key informan diperlukan dalam pemerolehan data dan informasi.

Dalam pengumpulan data penelitian, digunakan teknik observasi, dokumentasi, dan wawancara. Teknik observasi yang 
dilakukan yaitu observasi terstruktur dimana peneliti telah menyiapkan pedoman observasi. Instrumen observasi menggunakan daftar isian atau chek list. Metode dokumentasi digunakan untuk melengkapi data dan informasi lain yang diperoleh instansi terkait atau sumber referensi lain, termasuk studi pustaka. Lembar dokumentasi digunakan sebagai instrumen dalam penelitian ini. Proses wawancara dilakukan dengan bertatap muka secara langsung (face to face) dengan nara sumber atau key informan. Pedoman wawancara digunakan sebagai instrumen untuk memudahkan dalam proses wawancara dengan nara sumber atau key informan.

Analisis data dilakukan menggunakan tiga alur kegiatan yang terjadi secara bersamaan yaitu reduksi data, penyajian data, dan penarikan kesimpulan/verifikasi.

\section{HASIL DAN PEMBAHASAN}

Secara geografis wilayah Baduy terletak pada koordinat $6^{\circ} 27^{\prime} 27^{\prime \prime}-6^{\circ} 30^{\prime} 0^{\prime \prime}$ LS dan $108^{\circ} 3^{\prime} 9^{\prime \prime}$ - $106^{\circ} 4^{\prime} 55^{\prime \prime}$ BT, dan secara administratif wilayah Baduy termasuk dalam wilayah Desa kanekes, Kecamatan Leuwidamar, Kabupaten lebak, Provinsi Banten, dengan batas-batas wilayah sebagai berikut.

Sebelah utara, berbatasan dengan desa Bojongmenteng Kecamatan Leuwidamar, Desa Cisemeut Kecamatan Leuwidamar, dan Desa Nyagati Kecamatan Leuwidamar. Sebelah barat, berbatasan dengan Desa Parakanbeusi, Kecamatan Bojongmanik Kecamatan Bojongmanik, Desa keboncau Kecamatan Bojongmanik, dan Desa Karangnunggal Kecamatan Bojongmanik. Sebelah selatan, berbatasan dengan Desa Cikate Kecamatan Cijaku. Sebelah timur, berbatasan dengan Desa Karangcombong Kecamatan Muncang, Desa Cilebang Kecamatan Muncang.

Kampung Ciboleger, Kelurahan Bojongmenteng adalah "gerbang utama" untuk memasuki wilayah Baduy. Di tengah terminal Kampung Ciboleger terdapat tugu dengan patung yang menggambarkan satu keluarga Baduy yang seolah mengucapkan "selamat datang di Baduy". Di ujung jalan yang mendaki, sekitar 100 meter dari terminal adalah batas kawasan Baduy. Terdapat penanda dan peta sederhana kawasan Baduy, dipahat pada marmer penanda batas wilayah Baduy. Kampung Kaduketug Baduy Luar sebagai kampung terdepan. Kampung Kaduketug adalah pusat administrasi Desa Kanekes yang mencakup 57 kampung di seluruh kawasan Baduy. Masyarakat Baduy tinggal secara mengelompok pada suatu kampung dan menyebar di wilayah Kanekes. Ada dua kelompok besar pemukiman masyarakat Baduy, yaitu kelompok Baduy Dalam dan Kelompok Baduy Luar. Kelompok yang berada di Baduy Luar disebut masyarakat "panamping" yang artinya adalah pendamping, karena mereka bermukim di bagian luar wilayah Baduy dan mendampingi masyarakat Baduy Dalam. Kelompok Baduy Luar ini tersebar di 54 kampung. Sementara kelompok Baduy Dalam disebut dengan masyarakat "Kajeroan" yang artinya dalam atau "Girang" yang artinya hulu. Mereka bermukim di bagian dalam atau daerah hulu dari Sungai Ciujung. Ada tiga kampung yang mereka tinggali, yaitu Cikeusik, Cikartawana, dan Cibeo. Kelompok Baduy Dalam tidak pernah menambah jumlah kampung yang ada, wilayahnya hanya ada di tiga kampung tersebut. Sementara untuk Baduy Luar dari tahun ketahun jumlah kampungnya bertambah seiring dengan pertambahan populasi disana. Jika populasi di Baduy Dalam bertambah dan tidak sesuai dengan kapasitas kampungnya, maka sebagian dari mereka akan keluar untuk tinggal di wilayah Baduy Luar dan menjadi kelompok Baduy Luar.

Kampung-kampung Baduy Tangtu berada pada wilayah sebelah selatan, 
sedangkan kampung-kampung Baduy Panamping terletak di sebelah timur, barat, dan utara. Kampung-kampung tersebut umumnya berada di tepi atau dekat sungai. Jarak antar kampung bervariasi antara 0,5 km dan $1 \mathrm{~km}$ yang dihubungkan dengan jalan-jalan setapak yang penuh dengan tanjakan atau turunan mengikuti kontur perbukitan.

\section{Ketentuan Adat Masyarakat Baduy sebagai Kearifan Lokal yang Diterapkan pada Masyarakat Baduy}

Masyarakat Baduy percaya bahwa mereka adalah orang yang pertama kali diciptakan sebagai pengisi dunia dan bertempat tinggal di pusat bumi. Segala gerak laku masyarakat Baduy berpedoman kepada buyut karuhun (ketentuan adat). Seseorang tidak berhak dan tidak boleh melanggar dan mengubah tatanan kehidupan yang telah ada dan sudah berlaku turun temurun.

Puun adalah pimpinan tertinggi masyarakat Baduy. Dalam kehidupannya, puun adalah pimpinan tertinggi adat Baduy, merupakan keturunan batara serta dianggap sebagai penguasa agama Sunda Wiwitan yang harus ditaati segala perintah dan perkataannya. Rukun agama sunda wiwitan (rukun Baduy) yang terdiri dari ngukus, ngawalu, muja, ngalaksa, ngalanjak, ngapundayan, dan ngareksakeun sasaka pusaka, harus ditaati oleh seluruh masyarakat Baduy (Senoaji, 2011:17).

Pikukuh karuhun harus ditaati oleh masyarakat Baduy dan masyarakat luar yang sedang berkunjung ke Baduy. Ketentuan-ketentuan itu di antaranya sebagai berikut: (1) Dilarang mengubah jalan air, misalnya membuat kolam ikan, mengatur drainase, dan membuat irigasi. Oleh karena itu, sistem pertanian padinya adalah padi ladang. Pertanian padi sawah dilarang di komunitas Baduy; (2) Dilarang mengubah bentuk tanah, misalnya menggali tanah untuk membuat sumur, meratakan tanah untuk permukiman, dan mencangkul tanah untuk pertanian; (3) Dilarang masuk hutan titipan (leuweung titipan) untuk menebang pohon, membuka ladang, atau mengambil hasil hutan. Masyarakat Baduy membagi tata guna lahannya menjadi kawasan larangan, kawasan perlindungan, dan kawasan budidaya. Kawasan larangan dan perlindungan tidak dapat dialihfungsikan untuk kegiatan apapun; (4) Dilarang menggunakan teknologi kimia, misalnya menggunakan pupuk, obat pemberantas hama, mandi menggunakan sabun, pasta gigi, mencuci menggunakan detergen, atau meracun ikan; (5) Dilarang menanam tanamanbudidayaperkebunan,sepertikopi, kakao, cengkeh, kelapa sawit; (6) Dilarang memelihara binatang ternak berkaki empat, seperti sapi, kambing, kerbau; (7) Dilarang berladang sembarangan. Berladang harus sesuai dengan ketentuan adat; 8) Dilarang menggunakan sembarang pakaian. Ditentukan adanya keseragaman dalam berpakaian. Baduy Dalam berpakaian putih-putih dengan ikat kepala putih, Baduy Luar berpakaian hitam atau biru gelap dengan ikat kepala hitam atau biru gelap.

Buyut dan pikukuh karuhun dilafalkan dengan bahasa sunda kolot dalam bentuk ujaran yang disampaikan pada saat upacara-upacara adat atau akan diceriterakan oleh orang tua kepada anaknya. Ujaran-ujaran tersebut dinggap sebagai prinsip hidup masyarakat Baduy.

Menurut Djoewisno, 1987 dalam Senoaji (2011:18), orang Baduy berpegang teguh pada pedoman hidup yang dikenal dengan dasa sila, yaitu: (1) moal megatkeun nyawa nu lian (tidak membunuh orang lain); (2) moal mibanda pangaboga nu lian (tidak mengambil barang milik orang lain); (3) moal linyok moal bohong (tidak ingkar dan tidak bohong); (4) moal mirucaan kana inuman nu matak mabok (tidak minum minuman keras dan mabukmabukan); (5) moal midua ati ka nu sejen (tidak menduakan hari kepada orang lain/ 
poligami); (6) moal barang dahar dina waktu nu kungkung peting (tidak makan di malam hari); (7) moal make kekembangan jeung seuseungitan (tidak memakai wewangian); (8) moal ngageunah-geunah geusan sare (tidak melelapkan diri dalam tidur); (9) moal nyukakeun ati ku igel, gamelan, kawih, atawa tembang (tidak menyenangkan hari dengan tarian, musik, atau nyanyian); (10) moal make emas atawa salaka (tidak memakai emas atau permata). Dasar inilah yang melekat pada diri orang Baduy, menyatu dalam jiwa dan menjelma dalam perbuatan, tidak pernah tergoyahkan dengan kemajuan jaman. Hubungan dengan alam, hubungan antar masyarakat, hubungan antara laki-laki dan perempuan diatur dengan jelas dan tegas dan dipahami oleh semua masyarakat Baduy. Pesan itu tidak hanya merupakan nasihatyang berupa perintah karuhun saja, tetapi seolah-olah berupa suatu ketentuan yang menjadi pedoman bagi kehidupan sosial, karena itu apa yang dilarang adalah buyut (terlarang) untuk dilakukan oleh siapapun juga, seperti diungkapkan oleh pernyataan bahwa gunung teu meunang dilebur lebak teu meunang diruksak. larangan teu meunang dirempak. buyut teu meunang dirobah. lojor teu meunang dipotong. pondok teu meunang disambung (gunung tak boleh dihancurkan lembah tak boleh dirusak apa yang dilarang jangan dilakukan buyut janganlah diubah yang panjang janganlah dipotong yang pendek janganlah disambung) (Somantri, 1988).

Membuang sampah sembarangan bagi orang Baduy adalah suatu pekerjaan yang bertentangan dengan pitutur (peraturan hidup secara adat). Sebab hal itu akan membuat "kagetrak kagetruk" (tercemar)nya guriang bumi, yang menurut pitutur orang Baduy ditabukan. Dalam ungkapan bahasa yang modern, kagetrak kagetruk ialah merusak lingkungan hidup, sesuatu yang oleh masyarakat Baduy sangat dicegah dan diharamkan (Hamidimadja, 1997).

\section{Kearifan Lokal Masyarakat Baduy dalam Upaya Mitigasi Bencana}

Masyarakat Baduy hingga saat ini hidup dan menjalani kehidupan secara bersahaja, tetap memegang kuat kepercayaan dan adat istiadatnya, serta meniti hari demi hari dengan penuh kearifan. Salah satu bentuk kearifan lokal masyarakat Baduy yang cukup menonjol adalah berkaitan dengan pencegahan terhadap bencana atau mitigasi bencana.

Fakta dalam masyarakat Baduy menunjukkan bahwa (1) masyarakat Baduy melakukan tebang-bakar hutan untuk membuat ladang (huma), tetapi tidak pernah terjadi bencana kebakaran hutan; (2) di wilayah Baduy banyak hunian penduduk berdekatan dengan sungai, namun tidak pernah terjadi bencana banjir melanda permukiman; (3) walaupun rumah dan bangunan masyarakat Baduy terbuat dari bahan yang mudah terbakar (kayu, bambu, rumbia, dan ijuk), jarang terjadi bencana kebakaran hebat; dan (4) wilayah Baduy yang termasuk dalam daerah rawan gempa Jawa bagian Barat, tidak pernah terjadi kerusakan bangunan akibat bencana gempa.

Kearifan Lokal Tradisi Perladangan sebagai Mitigasi Bencana Longsor, Kebakaran, dan Bencana Lainnya

Sistem pertanian masyarakat Baduy yaitu dengan sistem pertanian berladang. Meskipun dalam bidang pertanian mereka tidak mengenal sarana dan prasarana pertanian yang modern serta hanya mengenal sistem perladangan, dimana sistem perladangan adalah sistem pertanian yang paling purba, namun mereka memiliki kearifan lokal yang sangat mengagumkan. Mereka sangat menghormati lingkungannya dengan tetap menjaga keseimbangan ekosistemnya. Mereka berprinsip bahwa jika keseimbangan tak terjaga, maka malapetaka akan datang dan akan menimpa 
mereka pula. Sebuah prinsip yang saat ini semakin terlepas pada diri kita yang sering menyebut "manusia modern" ini.

Beberapa aktivitas bertaninya yang menunjukkan nilai-nilai kearifan lokal diantaranya adalah mereka mempunyai pengetahuan yang handal tentang ilmu perbintangan. Ilmu perbintangan ini sangat penting artinya dalam dunia pertanian Baduy. Dengan melihat posisi bintang tertentu (bintang kidang dan bintang waluku), mereka bisa membaca cuaca atau musim beserta dengan perubahanperubahannya sehingga kerugian bertani akibat perubahan cuaca dapat dihindari.

Sementara itu, pada saat memulai penanaman padi di ladang, mereka tidak lupa menancapkan batang atau cabang daun pelah yang mempunyai bau khas. Hal ini dilakukan dengan tujuan untuk mencegah serangan hama penyakit dan hewan pengerat tikus. Batang atau cabang yang ditancapkan tersebut merupakan tempat yang sangat disukai capung dan capung-capung ini merupakan predator dan penghalau hama-hama tanaman padi. Burung-burung hantu juga sangat senang bertengger di cabang-cabang tersebut. Burung-burung hantu inilah yang menjadi predator bagi tikus-tikus ladang yang seringkali merusak tanaman padi. Setidaknya dengan keberadaan burungburung hantu ini keseimbangan alam atau lebih khususnya populasi tikus dapat dikendalikan.

Demikian juga dengan penggunaan penyubur tanaman dan pencegahan tanaman dari serangan hama penyakit. Penyubur dan pestisida terbuat dari campuran berbagai dedaunan yang ditumbuk halus dan dicampur dengan abu dapur. Semua bahan-bahan ini sangat ramah lingkungan dan bahannya tersedia di lingkungan mereka sendiri. Ini menunjukkan kemandirian mereka dalam bertani sekaligus kearifannya terhadap alam. Mereka telah mengenal dan menerapkan konsep yang disebut dengan integrated pest management atau pemberantasan hama terpadu yang dalam pertanian modern sekarang ini sangat dianjurkan.

Sementara itu, jenis tanaman padi yang ditanam adalah jenis padi lokal yang merupakan hasil seleksi sendiri. Meskipun masa tanamnya lebih lama namun jenis padi lokal mempunyai kualitas lebih baik, rasa dan aroma lebih enak, lebih tahan lama jika disimpan, lebih tahan terhadap hama penyakit, dan adaptif terhadap berbagai kondisi. Ini juga suatu bentuk kemandirian mereka lainnya dalam bidang pertanian.

Perladangan yang diterapkan di Baduy berpindah-pindah. Setiap tahun panen padi hanya satu kali saja. Lamanya masa tanam padi lima sampai enam bulan.Tanah yang ditinggal pergi oleh seorang peladang harus didiamkan dulu sebelum dijadikan lahan oleh warga lain agar kesuburannya terjaga. Jeda waktu sebelum tanah bisa ditanam lagi semakin singkat. Sekitar 10 tahun lalu tanah diistirahatkan sekitar 10 tahun, sekarang hanya didiamkan tiga sampai lima tahun. Siklus yang semakin cepat ini dipicu oleh pertambahan jumlah penduduk Baduy yang berefek pada kualitas dan kuantitas produksi padi.

Perpindahan ladang umumnya dilakukan setelah satu sampai dua kali panen, meskipun ada juga warga yang baru pindah ladang setelah empat kali panen. Hasil panen di tanah yang sama akan terus menurun setiap tahun. Setiap kali membuka ladang baru, ada tiga pekerjaan yang dilakukan, yaitu memangkas tumbuhan yang ada di tempat, membakar tumbuhan, dan membersihkan tanah dari benda-benda yang mengganggu perladangan. Tanah tidak dibajak demi menjaga kekuatan tanah di tanah Baduy. Setelah tanah siap, dimulailah tanam padi atau yang dikenal dengan nama ngaseuk. Sebelum mulai menanam padi, suku Baduy mengadakan upacara untuk memuji Dewi 
Sri, yang dikenal sebagai dewi padi, agar melindungi tanah mereka. Dalam upacara ini, ada mantra-mantra yang diiringi alunan angklung dan kendang kecil (dog-dog). Pemain angklung bertugas membacakan mantra. Upacara ini wajib diadakan di setiap kampung. Warga yang mampu juga boleh mengadakan upacara ini bagi mereka masing-masing. Upacara yang diadakan setiap keluarga sifatnya tidak wajib sebab untuk upacara ini tuan rumah harus menyediakan makan dan kebutuhan lain.

Masa tanam padi di kampungkampung Baduy dimulai ketika puun sudah menanam padi. Setelah puun, warga mulai menanam. Beberapa warga memiliki hari baik yang mereka jadikan pegangan untuk mulai menanam padi. Setelah masa tanam warga Baduy tidak lagi mengurus huma mereka secara teratur. Mereka hanya membersihkan ladang dari tumbuhan-tumbuhan yang dapat mengurangi produksi padi. Pengairan ladang dilakukan tanpa irigasi dan hanya mengandalkan hujan.

Secara umum dan garis besar, tahapan kerja bercocok tanam di ladang pada masyarakat suku Baduy adalah sebagai berikut.

Pertama, suatu areal hutan yang akan dibuka terlebih dahulu dibersihkan semak belukarnya, yang disebut dengan nyacar dan biasanya dilakukan oleh lakilaki dewasa dengan menggunakan alat antara lain golok dan parang. Pekerjaan itu adakalanya dibantu pula oleh wanita dewasa.

Kedua, setelah hutan dibersihkan, kemudian dilakukan penebangan pohonpohon besar dengan menggunakan kapak, patik atau baliung (sejenis kapak besar).

Ketiga, selanjutnya ranting-ranting kayu dibakar, pembakaran hutan yang sudah ditebang pada dasarnya adalah cara untuk mempercepat proses pembusukan dan sekaligus mengarahkan proses itu sedemikian rupa sehingga zat makanan yang dilepaskan tersalur sebanyak mungkin ke dalam tanaman penghasil pangan yang sudah dipilih. Proporsi yang cukup besar dari energi mineral yang menghidupi tanaman ladang itu khususnya padi-padian, lebih banyak berasal dari abu hutan yang dibakar, sehingga sempurnanya pembakaran itu merupakan faktor penting untuk menentukan hasil panen kelak, suatu kenyataan yang barangkali memang disadari oleh semua peladang.

Keempat, setelah areal hutan dibakar biasanya tidak langsung digarap, tetapi dibiarkan beberapa waktu lamanya sehingga tanah menjadi dingin. Ketiga, tahap berikutnya adalah penanaman benih berupa padi-padiandan biji-bijian lainnya. Kegiatan ini dilakukan oleh laki-laki dan wanita, pekerjaan ini disebut ngaseuk, yaitu melobangi tanah untuk menanam benih dengan aseuk (tongkat kayu dengan panjang kira-kira satu setengah meter yang ujungnya dibuat agak runcing). Selain padi, di tanah huma ditanam pula kacang-kacangan dan biji-bijian, misalnya jagung, bahkan di daerah Banten orang mulai menanam tanaman keras, seperti kelapa dan buah-buahan. Keempat, selama menunggu masa panen (3-4 bulan), huma perlu dibersihkan dari rumput-rumputan yang tumbuh. Keempat, selama menunggu masa panen (3-4 bulan), huma perlu dibersihkan dari rumput-rumputan yang tumbuh di sekitar tanaman. Pekerjaan ini disebut ngoyos (menyiangi). Pada perkembangan selanjutnya,dalam pekerjaan ngaseuk dan ngoyos digunakan peralatan berupa cangkul dan kored (sejenis cangkul kecil).

Kelima, tahap kelima adalah masa panen. Pekerjaan panen biasanya dilakukan oleh wanita secara gotongroyong, sedangkan laki-laki bertugas mengangkut hasil panen ke rumah masingmasing. Pada setiap tahap dari kegiatan tersebut di atas, terutama kegiatan panen selalu disertai dengan upacara selamatan agar usaha pertanian itu tidak mengalami 
ganggguan atau diserang hama. Upacara itu merupakan perwujudan dari kepercayaan terhadap alam gaib dalam kehidupan manusia, sebagai bagian dari budaya animisme dan dinamisme.

Dalam hubungan ini masyarakat Baduy tetap mempertahankan mata pencaharian ngahuma, karena hingga kini mereka masih tetap tabu/pamali (dilarang secara adat) untuk mengolah tanah pertanian mereka dengan pola pertanian sawah. Bila dianalisa lebih jauh, hal tersebut disebabkan oleh beberapa faktor. Pertama, tanah pertanian masyarakat Baduy terletak diperbukitan sehingga sulit dibuatkan irigasi. Kedua, dibalik tabu itu terkandung makna, bahwa mereka mungkin secara tidak disadari sebenarnya telah merasakan manfaat ekosistem. Itulah sebabnya huma di daerah Baduy ditanami pula dengan tanaman keras sebagai pelindung tanah, sehingga tanah pertanian mereka tetap subur. Ketiga, mereka sangat percaya terhadap alam/kekuatan gaib. Suatu areal huma biasanya diolah selama satu sampai tiga tahun. Setelah itu huma dibiarkan menjadi hutan kembali.

Menurut tradisi masyarakat Baduy dikenal lima macam huma, yakni: (a) huma serang, ladang adat kepunyaan bersama yang hanya terdapat di Baduy Tangtu (awam menyebutnya Baduy Dalam), yaitu di Cikeusik, Cikartawana, dan Cibeo, (b) huma puun, ladang dinas selama menjabat sebagai puun yang letaknya tidak jauh di belakang rumah puun, (c) huma tangtu, ladang untuk keperluan penduduk Baduy Tangtu, (d) huma tuladan, ladang untuk keperluan upacara (seperti huma serang) di Baduy Panamping (Baduy Luar), dan (e) huma panamping, ladang untuk keperluan penduduk Baduy Panamping (Permana, 2010:52-54).

Huma serang dibuka dan ditanam terlebih dahulu, kemudian diikuti dengan huma puun, huma tangtu, lalu huma tuladan dan huma panamping. Jenisjenis huma tersebut merupakan strategi ketahanan pangan masyarakat Baduy. Dalam adat Baduy, padi yang dihasilkan terutama untuk keperluan upacara adat dan keperluan sehari-hari, serta tidak boleh diperjualbelikan.

Hasil padi dari huma serang untuk keperluan upacara adat Baduy Tangtu dan keseluruhan Baduy, sedangkan padi dari huma panamping untuk upacara adat di wilayah panamping. Jika terjadi gagal panen di huma serang, maka padi upacara diambil dari huma panamping. Jika keduanya gagal panen, maka padi diambil dari huma tangtu dan huma panamping. Strategi itu merupakan antisipasi kegagalan panen misalnya akibat cuaca yang tidak menentu dan serangan hama. Dengan membuka ladang yang tidak bersamaan dan pada tempat yang berbeda, maka kegagalan panen dapat dihindari (Permana, 2010:54-55).

Kearifan lokal masyarakat Baduy dalam tradisi perladangan yang berdampak pada mitigasi bencana terlihat dalam tradisi pemilihan dan pembakaran lahan ladang (huma). Tradisi pemilihan lahan ladang berkaitan dengan mitigasi bencana tanah longsor, sedangkan tradisi pembakaran lahan ladang berkaitan dengan mitigasi kebakaran hutan.

Menurut pengetahuan yang turuntemurun dari sejumlah informan dan narasumber diketahui bahwa pemilihan lahan huma didasarkan atas jenis tanah, kandungan humus, dan kemiringan lereng. Dari segi jenis tanahnya dapat dilihat berdasarkan warna, kandungan air dan udara, serta kandungan batu. Berdasarkan warnanya dikenal taneuh hideung (tanah hitam), taneuh bodas (tanah putih), dan taneuh beureum (tanah merah). Tanah hitam merupakan prioritas karena tanah tersebut banyak mengandung surubuk (humus). Berdasarkan kandungan air dan udaranya dikenal taneuh liket (tanah lengket) dan taneuh bear (tanah gembur). Untuk memperoleh lahan huma yang baik, maka sebaiknya dipilih taneuh bear 
karena pada tanah ini selain terdapat air, juga longgar dan terdapat banyak udara sehingga akar tanaman bisa bebas bergerak dan bernapas. Sementara itu, berdasarkan kandungan batunya, lahan yang baik adalah taneuh teu aya batuna (tanah yang tidak ada batunya) dan jangan memilih taneuh karang (tanah yang banyak terdapat batu).

Dari segi kandungan humusnya dapat dilihat dari banyak tidaknya surubuk dan koleang. Surubuk merupakan istilah Baduy untuk menyebut humus sebagai kandungan dalam tanah yang dapat menyuburkan tanaman, sedangkan koleang berupa daun-daun kering yang jatuh atau terdapat pada permukaan tanah. Kedua unsur ini sangat penting bagi masyarakat Baduy sebagai pupuk organik. Berbeda dengan jenis tanah dan kandungan humus, segi kemiringan lereng lebih berkaitan langsung dengan mitigasi bencana. Menurut para informan, dari segi kemiringan lereng orang Baduy membedakannya menjadi lahan gedeng (lahan yang miring atau curam) dan lahan cepak (lahan di tempat datar). Pilihan terbaik untuk lahan ladang adalah lahan cepak. Secara praktis lahan tersebut lebih mudah dalam pembukaan dan pengelolaan lahan. Tetapi dalam kenyataan di lapangan didapati bahwa bentukan permukaan lahan di wilayah Baduy jarang sekali ditemukan tanah yang datar sehingga banyak ladang ditemukan pada lahan gedeng. Oleh karena itu, upaya mitigasi longsor yang dilakukan adalah dengan tidak menebang pohon-pohon besar yang terdapat di lahan tersebut. Selain itu, untuk menjaga agar humus tanah tidak terbawa air hujan, maka pada lereng tersebut biasanya dibuat teras-teras penahan yang terbuat dari potongan-potongan kayu.

Kearifan lokal dalam kaitannya dengan mitigasi kebakaran hutan terlihat dalam tradisi ngahuru atau ngaduruk, yakni membakar tebangan sehabis membuka ladang. Dahan, ranting, dedaunan dan rerumputan bekas potongan/tebasan harus dikeringkan dan dionggokkan untuk dibakar. Kegiatan pengonggokan 'sampah' tersebut disebut dangdang (Baduy Panamping) atau nyampurai (Baduy Tangtu). Kegiatan yang dilakukan adalah membuat onggokan besar di tengah-tengah ladang yang diperoleh dari 'sampah' di sekelilingnya. Kemudian tidak begitu jauh dari onggokan besar di tengah tersebut dibuat onggokanonggokan lebih kecil mengitarinya. Di antara onggokan-onggokan tersebut tidak boleh ada 'sampah' yang tersisa agar ketika pembakaran api tidak menjalar ke mana-mana. Demikian pula, antara anggokan-onggokan kecil 'sampah' dan batas ladang juga harus dibuat bersih, agar api tidak menjalar ke luar ladang yang dapat menyebabkan kebakaran hutan atau ladang milik warga lain.

Awal kegiatan ngahuru atau ngaduruk ini harus berpatokan pada pertanggalan bintang. Dalam ungkapan yang diutarakan oleh Sangsang (48 tahun), informan dari kampung Cibeo (Baduy Tangtu), "gek kidang ngarangsang kudu ngahuru", yang artinya lebih kurang adalah "jika melihat bintang kidang (waluku) seperti pada posisi matahari pagi, maka waktunya mulai membakar sisa-sisa tebangan di ladang". Daerah Baduy saat membakar onggokanonggokan'sampah' ladang tersebut seolaholah sedang terjadi kebakaran hutan, karena asap mengepul di mana-mana. Walaupun demikian, pada saat kegiatan ini tidak pernah terjadi kebakaran hutan. Selama pembakaran selalu dijaga agar api tidak merambat kemana-mana. Bila akan ditinggalkan harus dipastikan bahwa api dan bara telah benar-benar padam. Abu sisa pembakaran ini dibiarkan tertinggal pada lapisan atas tanah sebagai pupuk sambil menunggu hujan tiba.

Tradisi Baduy juga mengajarkan bahwa dalam perladangan dilarang (buyut) menggunakan peralatan pacul apalagi bajak. Alat-alat tersebut dapat 
menyebabkan tanah menjadi terbolakbalik dan permukaan tanah berubah. Terbolak-balik dan berubahnya permukaan tanah diyakini akan berdampak pada ketidakstabilan permukaan tanah dan dapat mengakibatkan tanah longsor. Oleh karena itu, dalam tradisi menanam benih padi di ladang hanya menggunakan tongkat kayu (tugal) yang disebut aseuk. Kegiatan menugal atau membuat lubang-lubang kecil untuk memasukkan benih padi tersebut disebut ngaseuk.

Kearifan Lokal dan Aturan Adat pada Syarat Bangun Bangunan Tradisional sebagai Bentuk Mitigasi Bencana Gempa Bumi, Kebakaran, Banjir, dan Bencana Lainnya

Permukiman di masyarakat badui ditentukan oleh puun, bangunan yang akan didirikan harus sesuai dengan struktur tanah dan letak topografi daerah tersebut. Kondisi rumah, bentuk rumah, susunan ruangan sudah disesuaikan dengan ketentuan adat. Walaupun mereka memiliki tanah tetapi mereka tidak boleh mendirikan bangunan secara sembarangan tanpa ada perijinan dari ketua adat terlebih dahulu. Sebelum mereka mendirikan rumah lahan yang akan digunakan harus diterawang oleh ketua adat, apakah lokasi tersebut sudah cocok atau tidak untuk mendirikan rumah. Bentuk bangunan permukiman masyarakat Badui rata-rata memiliki bentuk yang sama yaitu ruangan rumah dibagi menjadi tiga bagian yaitu: (a) Teras (sasoro); (b) Ruang tengah (depas); (c) Dapur (imah).

Bentuk arsitektur bangunan rumah dan bangunan lainnya dikaitkan dengan kondisi lingkungan seperti: (a) Atap terbuat dari daun aren (kirey) dan ijuk, berfungsi untuk menghindari ruangan dalam rumah saat hujan turun agar air tidak masuk kedalam rumah dan dapat langsung terkena sinar terik matahari sehingga ruangan dari rumah terhindar dari kelembapan. (b) Tiang terbuat dari kayu mahoni, karena kayu mahoni termasuk kayu yang paling kuat sehingga mengantisipasi agar rumah tidak cepat roboh dan tahan terhadap bencana alam seperti angin, air hujan, dan gempa. (c) Dinding rumah terbuat dari bambu (dalam bentuk anyaman). Bambu termasuk tumbuhan yang elastis sehingga mudah dijadikan penutup rumah. Fungsinya tahan terhadap angin dan memberikan efek sejuk di dalam rumah.

Selain itu bentuk bagunan masyarakat Baduy rata-rata memiliki bentuk yang sama, hal ini menunjukkan kesederhanaan di dalam lingkungan masyarakat. Bentuk permukiman dari tiap-tiap rumah saling berkelompok sesuai dengan topografi yang ada. Letak permukimannya berada di pinggir sungai.

Teknologi yang dimiliki oleh masyarakat Baduy dalam mendirikan bangunan masih tergolong sederhana, namun menjunjung tinggi kearifan lingkungan. Bangunan rumah Baduy umumnya berbentuk sama berupa rumah panggung sederhana dari bahan kayu, bambu, ijuk dan rumbia. Rumah panggung ini mempunyai ukuran yang hampir sama. Menurut Sarpin (42 tahun) warga kampung Balimbing (Baduy Panamping) tentang rumah yang sama dan sederhana tersebut: "...kudu sarua ulah aya anu luhur handapan hirup sadarahana..." (yang maksudnya: harus sama tidak boleh ada yang tinggi atau rendah dan hidup dalam kesederhanaan). Pernyataan tersebut juga bermakna kesetaraan setiap warga Baduy selama hidup di dunia. Menurut keyakinan orang Baduy, mereka akan berbeda jika sudah berada di alam setelah meninggal bergantung pada amal kebajikannya di dunia.

Rumah Baduy yang berbentuk panggung secara umum berkaitan erat dengan kepercayaan bahwa rumah sebagai pusat yang memiliki kekuatan netral yang terletak di antara dunia bawah dan 
dunia atas. Rumah tidak boleh didirikan langsung menyentuh tanah (sebagai bagian dari dunia bawah). Oleh karena itu, rumah dibuat dengan cara memasang tiang-tiang kolong yang ditegakkan di atas batu umpak. Secara khusus, rumah Baduy berdasarkan susunan vertikalnya merupakan cerminan pembagian jagat raya. Kaki atau tiang melambangkan dunia bawah (dunia kegelapan, neraka), tubuh atau dinding dan ruang di dalamnya melambangkan dunia tengah (dunia kehidupan alam semesta), dan kepala atau atap melambangkan dunia atas (dunia abadi, kahyangan). Jika rumah tanpa kaki dianggapnya sama saja dengan hidup di dunia bawah, atau jika rumah menggunakan atap genting, sama artinya dengan dikubur hidup-hidup (karena genting terbuat dari tanah) (Permana, 2010:82-83).

Khusus pada masyarakat Baduy Tangtu bila mendirikan rumah pada tanah yang miring, maka tidak boleh meratakan tanah tersebut. Meratakan tanah berarti akan merusak dan membolak-balik tanah. Membolak-balik tanah berarti melanggar pikukuh. Untuk memperoleh lantai rumah yang rata, maka tihang (tiang) rumah diatur ketinggiannya. Tanah yang merendah dibuatkan tiang yang lebih tinggi dibandingkan tiang pada tanah yang meninggi. Dengan demikian, jika kita memasuki permukiman Baduy Tangtu akan terlihat jelas bentuk kontur atau permukaan tanah aslinya. Air hujan akan mengalir mengikuti jalan alamiahnya. Karena tidak ada rekayasa yang bertentangan dengan apa adanya, maka tidak pernah terjadi erosi, tanah longsor, atau banjir di permukiman-permukiman Baduy tersebut.

Kearifan lokal masyarakat Baduy dalam tradisi bangunan tradisional yang berkaitan dengan mitigasi bencana gempa (lini) terdapat pada konstruksi, teknik sambung dan ikat bangunan, serta penggunaan umpak. Konstruksi bangunan rumah menggunakan bahan berasal dari lingkungan mereka sendiri seperti kayu dan bambu. Struktur bangunan didirikan atas sistem rangka yang terbuat dari kayu berupa balok dan tiang persegi empat. Struktur penutup dinding terbuat anyaman bambu (bilik/geribig) yang dibiarkan warna dan karakter aslinya. Bambu-bambu yang dibelah juga digunakan untuk menjadi struktur penutup pada pengakhiran anyaman bambu. Semua rincian konstruksi diselesaikan dengan prinsipprinsip ikatan, tumpuan, pasak, tumpuan berpaut dan sambungan berkait. Orang Baduy Tangtu dilarang menggunakan paku dalam pembuatan rumah. Untuk pengikat umumnya digunakan rotan dan bambu, atau dengan teknik pasak. Struktur lantai rumah umumnya digunakan bambu yang yang dibuat berbentuk lembaranlembaran disebut palupuh.

Sementara itu, untuk struktur utama hateup (atap) digunakan atap rumbia (kiray) dengan bambu dan rotan sebagai pengikat. Jika terjadi gempa, maka struktur rumah akan bergerak dinamis sehingga terhindar dari kerusakan atau kehancuran. Selain itu, baik rumah masyarakat Baduy Tangtu maupun Baduy Panamping, semuanya didirikan di atas umpak batu (dedel). Hal itu menurut penjelasan dari para narasumber bermakna filosofis bahwa rumah Baduy sebagai pusat antara dunia bawah dan dunia atas. Dalam kaitan ini, umpak batu menjadikan rumah tidak menyentuh tanah yang melambangkan dunia bawah. Secara praktis, umpak batu juga berfungsi mencegah rayap atau pelapukan tiang rumah akibat udara basah atau lembab pegunungan. Secara teknis, struktur dan sambungannyalah yang menunjukkan adanya kearifan lokal yang terkait dengan mitigasi bencana. Sedangkan secara simbolis, umpak menunjukkan kepercayaan yang terkait dengan alam, yaitu dipandang sebagai perantara antara dunia tengah dan dunia bawah. 
Adanya hawu dan parako di dalam rumah juga merupakan kearifan lokal tersendiri. Hawu bila berdiri sendiri berfungsi sebagai perapian berupa bidang segi empat yang sisi-sisinya terbuat dari kayu/papan yang diisi tanah (bawah) dan abu (atas). Namun bila bersama parako (tungku dari tanah liat), maka hawu berfungsi sebagai dasar tungku. Dengan adanya hawu, maka berfungsi mencegah kebakaran karena api atau bara pada parako tidak membakar lantai palupuh yang ada di bawahnya.

Selain rumah tinggal, ada satu bangunan penting bagimasyarakat Baduy, yakni lumbung (leuit). Seperti halnya bangunan rumah, lumbung juga dibuat dengan menggunakan bahan alami seperti kayu dan bambu, serta atap dari rumbia atau ijuk. Lumbung-lumbung ini terletak berkelompok di luar permukiman. Biasanya tiap keluarga memiliki satu hingga tiga buah lumbung. Bangunan ini umumnya berukuran $1,5 \times 1,5 \mathrm{~m}$ sampai $2 \times 2 \mathrm{~m}$. Bangunan lumbung juga memiliki kolong dengan tinggi kaki sekitar 1 sampai 1,5 meter. Secara umum terdapat dua jenis bangunan lumbung, yakni lumbung yang memiliki geuleubeug dan lumbung tanpa geuleubeug. Bangunan lumbung yang memiliki geuleubeug adalah lumbung yang pada bagian atas kaki bangunan terdapat semacam piringan bulat dari kayu dengan diameter 30-50 cm yang terletak sekitar 30 $\mathrm{cm}$ di bawah lantai lumbung. Fungsi dari piringan ini adalah untuk mencegah agar tikus atau binatang pengerat lainnya tidak dapat naik dan masuk ke dalam lumbung. Bagian badan dari lumbung ini agak mengecil ke arah bagian bawah. Lumbung tanpa geuleubeug berukuran lebih pendek. Bagian badan lumbung memiliki ukuran yang sama dari bagian atas hingga bawah. Bentuk lumbung seperti ini banyak dijumpai dan dibuat saat ini.

Pengetahuan tentang peletakan lumbung-lumbung terpisah dari permukiman merupakan kearifan lokal masyarakat Baduy yang khas sebagai mitigasi bencana kebakaran rumah atau kampung. Tidak ada pola khusus peletakan lumbung, ada yang berada di seberang sungai, di balik hutan kampung, di lereng bukit, atau pada jarak 10-20 meter dari rumah terakhir. Selain itu, seperti halnya bangunan rumah, lumbung ini juga didirikan di atas tiang yang dilandasi oleh umpak batu kali. Selain secara teknis untuk mencegah pelapukan kaki bangunan, cara ini juga dapat menjaga kelenturan

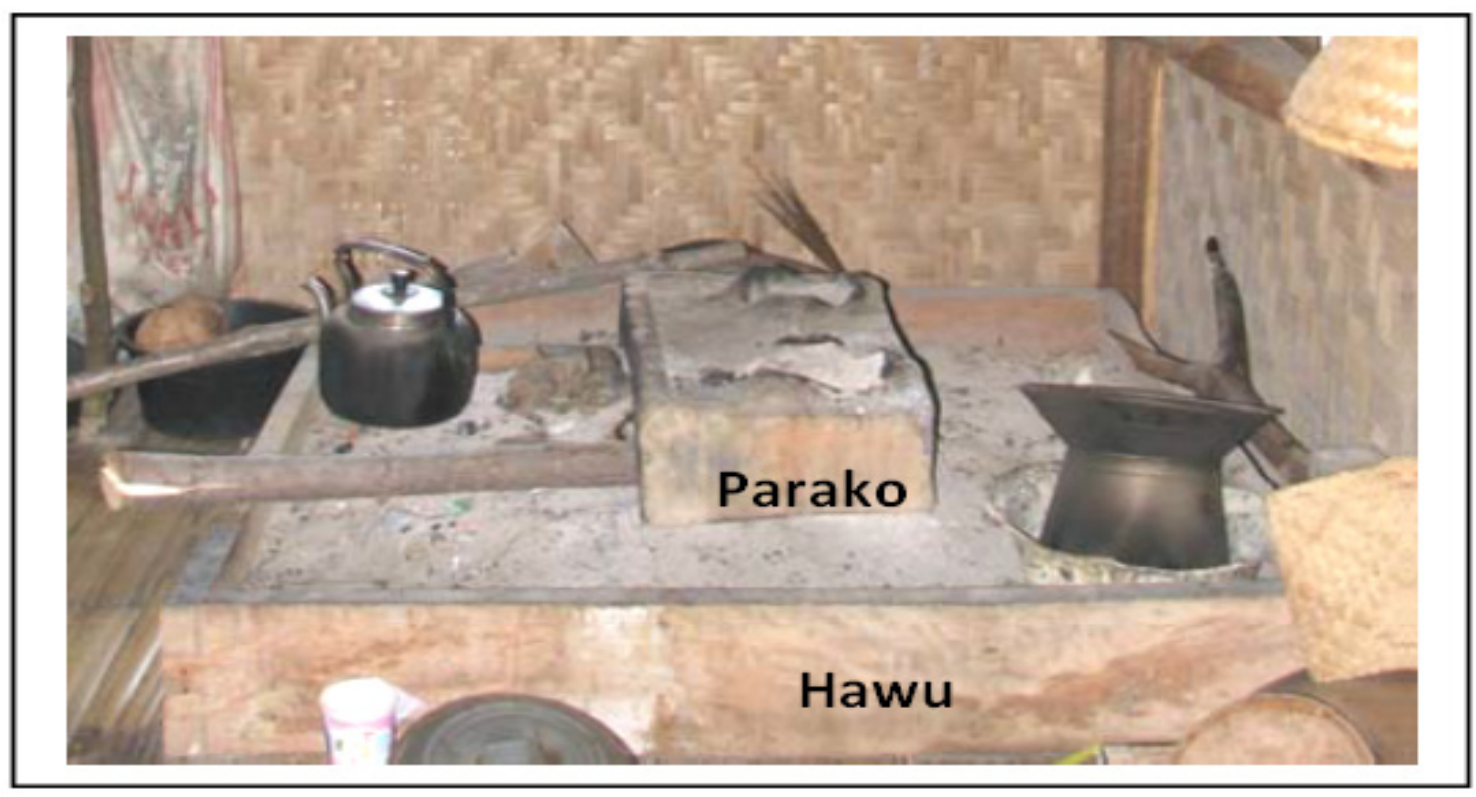

Gambar 1. Hawu dan Parako di dalam Rumah Adat Baduy 
bangunan jika terjadi goncangan gempa hingga bangunan tidak roboh.

\section{Kearifan Lokal tentang Pengelolaan Hutan dan Air sebagai Wujud Mitigasi Bencana Banjir dan Longsor}

Bagi masyarakat yang hidup dan tinggal di sektar hutan, keberadaan hutan dengan seluruh potensi sumber daya alam yang terkandung di dalamnya sangat penting bagi kelangsungan hidup komunitas masyarakat tersebut, tak terkecuali masyarakat Baduy. Hutan dimaknai sebagai sumber makanan, minuman, obatobatan, pemenuhan kelengkapan hidup, perlindungan, dan kenyamanan, tempat ritual dan pranata kepercayaan, serta tempat untuk mengembangkan kesetiakawanan sosial anggota masyarakat setempat.

Mengingat pentingnya fungsi hutan bagi kelangsungan hidup komunitas masyarakat tersebut, maka terbentuk dan berkembanglah kearifan lokal yang ditujukan untuk menjaga kelestarian fungsi lingkungan hidup. Terbentuknya kearifan lokal sebagai hasil dari pola adaptasi atau bentuk-bentuk hubungan yang dikembangkan masyarakat denga lingkungan hidupnya.

Di antara kearifan lokal yang dihasil-kan daripengalamanadaptasimasyarakatdengan lingkungannya, khususnya hu-tan adalah konsep "hutan larangan" yang bersumber pada pandangan dan pengetahuan masyarakat (traditional knowledge) dalam upaya pengelolaan lingkungan secara tradisional. Melalui konsep hutan larangan, masyarakat menerapkan norma pengendali sikap dan perilaku hidup dalam pengelolaan hutan dengan cara melakukan penataan, pemanfaatan, pengembangan, pemeliharaan, pemulihan, pengawasan, dan pengendalian hutan.

Pandangan hidup masyarakat Baduy terhadap hutan yaitu mereka menganggap gunung dan hutan adalah sumber penghidupan masyarakat Baduy, alam tidak hanya untuk menghidupi masyarakat Baduy tapi untuk masyarakat luas. Masyarakat Baduy menganggap alam bukanlah sumber daya yang harus dieksploitasi untuk mendapatkan keuntungan sebesar-besarnya, akan tetapi alam merupakan titipan dari Tuhan untuk dijaga manusia agar dimanfaatkan oleh generasi yang akan datang.

Masyarakat Baduy berpendapat bahwa dirinya diciptakan untuk menjaga tanah larangan yang merupakan pusat bumi Mereka dituntut untuk menyelamatkan hutan titipan dengan menerapkan pola hidup seadanya yang diatur oleh norma adat. Oleh karena itu, kegiatan utama masyarakat Baduy pada hakikatnya terdiri atas pengelolaan lahan untuk kegiatan pertanian (ngahuma) dan pengelolaan serta pemeliharaan hutan untuk perlindungan lingkungan. Pekerjaan ngahuma bukan mata pencaharian, tetapi juga merupakan ibadah yang merupakan bagian dari rukun Baduy. Kegiatan berladang dianggap sebagai kegiatan yang suci, karena mengawinkan dewi padi atau Nyi Pohaci Sanghyang Asri. Kegiatan berladang akan selalu diikuti dengan upacaraupacara yang dipimpin oleh ketau adat.

Kearifan lokal masyarakat Baduy pada hutan dan air dalam kaitannya dengan mitigasi bencana banjir dan longor tercermin dalam fungsi dan letak hutan dan air. Berdasarkan pemaparan dari Jaro Daenah (58 tahun) yang juga Kepala Desa Kanekes (Jaro Pamarentah), fungsi hutan terbagi menjadi tiga jenis, yaitu hutan larangan, hutandungusan atau dudungusan, dan hutan garapan. Hutan larangan adalah hutan lindung yang tidak boleh dimasuki oleh sembarang orang yang di dalamnya, bahkan orang Baduy atau pimpinan adat sekalipun. Hutan dudungusan adalah hutan yang dilestarikan karena berada di hulu sungai, atau di dalamnya dianggap terdapat keramat atau diyakini sebagai tempat leluhur Baduy. Sementara itu, hutan garapan adalah hutan yang dapat digarap untuk dijadikan ladang (huma) 
oleh masyarakat Baduy secara umum. Hutan larangan terdapat di wilayah hutan lindung di selatan Baduy tangtu.

Hutan dungusan atau dudungusan berfungsi untuk melindungi hulu sungai. Hutan dudungusan ini terdapat di huluhulu sungai antara lain dudungusan Cihalang (terletak antara kampung Gajeboh dan Cicatang), dudungusan Cikondang (antara kampung Gajeboh dan Cicakal), dudungusan Cimambiru (dekat kampung Balimbing), dudungusan Cigaru (dekat kampung Gajeboh), dudungusan Jambu (dekat kampung Cicakal), dudungusan Cikuya (dekat kampung Marengo), dan dudungusan Kalagian (dekat kampung Cibeo). Para informan mengungkapkan bahwa hutan dudungusan itu dilindungi untuk menjaga keberlanjutan air dan sungai untuk kebutuhan vital masyarakat sehari-hari. Hutan-hutan di sekitar atau sepanjang daerah aliran sungai (DAS) juga berfungsi untuk menahan erosi atau kikisan tepi sungai yang dapat menyebabkan banjir atau air sungai menjadi keruh atau kotor. Hutan garapan merupakan lahan tempat orang Baduy dapat membuka dan mengerjakan ladangnya.

\section{SIMPULAN}

Hampir setiap masyarakat memiliki kearifan lokal yang khas sebagai strategi adaptasi terhadap lingkungan. Dengan kearifan tersebut suatu masyarakat dapat bertahan dan berhasil menjalani kehidupannya dengan baik. Strategi untuk keberhasilan dalam kehidupan suatu masyarakat itu tidak terlepas dari kepercayaan dan adat istiadat yang diajarkan dan dipraktikkan secara turun temurun dari generasi ke generasi.

Kearifan lokal disimpulkan sebagai kepribadian, identitas kultural masyarakat yang berupa nilai, norma, etika, kepercayaan, adat istiadat, dan aturan khusus yang diterima oleh masyarakatnya dan teruji kemampuannya sehingga dapat bertahan secara terus menerus. Kearifan lokal pada prinsipnya bernilai baik dan merupakan keunggulan budaya masyarakat setempat yang berkaitan dengan kondisi geografis secara luas.

Pada masyarakat Baduy yang hingga kini hidup dan menjalani kehidupannya secara bersahaja, tetap memegang kuat kepercayaan dan adat istiadatnya serta meniti hari demi hari dengan penuh kearifan. Kepercayaan dan adat istiadat itu menjadi pikukuh yang senantiasa menjadi falsafah hidup dan keseharian masyarakat Baduy. Nenek moyang atau leluhur Baduy melalui pikukuh-nya mengajarkan bahwa berpikir, berkata, dan berbuat haruslah sesuai dengan aturan dan ketentuan yang telah ditetapkan. Aturan-aturan tersebut tidak boleh dikurangi atau ditambahi semaunya. Pikukuh itu juga mengajarkan kejujuran dan selalu menjaga kebenaran dan kebaikan untuk kemaslahatan dan keselamatan.

Salah satu bentuk kearifan lokal masyarakat Baduy itu adalah berkaitan dengan pencegahan terjadinya bencana atau mitigasi bencana. Masyarakat Baduy melalui kearifan lokalnya terbukti mampu melakukan pencegahan atau mitigasi bencana, baik bencana gempa bumi, banjir, tanah longsor, maupun kebakaran melalui tradisi yang tercermin dalam:

Pertama. Tradisi perladangan, yakni aturan-aturan atau pikukuh yang harus diikuti dan ditaati mulai dari pemilihan lokasi untuk perladangan, waktu untuk mulai berladang (ngahuma), tanaman yang boleh ditanam, tata cara membuka dan membakar hutan, hingga peralatan yang diperbolehkan untuk digunakan dalam berladang. Kearifan lokal dalam tradisi perladangan masyarakat Baduy merupakan salah satu bentuk mitigasi bencana, terutama bencana longsor, banjir, dan kebakaran.

Kedua. Aturan adat atau pikukuh dalam tradisi membangun bangunan tradisional dengan larangan dan aturan terhadap bahan dan peralatan bangunan 
merupakan salah satu bentuk mitigasi terhadap bahaya atau bencana gempa bumi, banjir, dan kebakaran. Bahan bangunan dari bambu, ijuk, dan kiray untuk bangunan rumah merupakan bahan yang lentur dan tidak mudah rusak. Bangunan yang didirikan di atas umpak, tidak boleh langsung menyentuh tanah membuat bangunan tidak akan mudah roboh sekalipun terjadi bencana gempa bumi yang hebat. Aturan pembuatan kolomkolom bangunan dan sambungan tidak boleh menggunakan paku, hanya pasak dan tali ijuk merupakan mitigasi terhadap bencana gempa bumi. Bangun bangunan didirikan dengan tidak boleh merobah atau merusak kontur tanah, merupakan bentuk mitigasi terhadap longsor dan banjir. Adanya hawu dan parako sebagai peralatan rumah tangga untuk memasak merupakan wujud antisipasi terhadap bahaya kebakaran.

Ketiga. Kearifan lokal masyarakat Baduy berupa pikukuh dan aturan adat dalam pengelolaan lahan, hutan, dan air, dengan membagi wilayah hutan dalam tiga zonasi, yaitu zona leuweung kolot, zona huma dan reuma, serta zona lembur dan dukuh lembur merupakan wujud mitigasi bencana alam longsor, dan banjir, dan bencana lainnya. Pembagian wilayah hutan atau zonasi tersebut telah menjaga ekosistem alam tetap lestari dan menjadi penyangga bagi seluruh kehidupan masyarakat Baduy dan sekitarnya.

\section{DAFTAR PUSTAKA}

Hamidimadja, N. (1998). "Baduy Tanah Karuhun Menusuk Kalbu”. Bulletin KAWIT 50/1998.

Marfai, M.A. (2012). Pengantar Etika Lingkungan dan Kearifan Lokal. Yogyakarta: Gadjah Mada University Press.

Permana, C.E. (2010). Kearifan Lokal Masyarakat Baduy dalam Mitigasi Bencana. Jakarta: Wedatama Widya Sastra.

Priambodo, S.A. (2009). Panduan Praktis Mengatasi Bencana. Yogyakarta: Kanisius.

Sartini. (2009). Mutiara Kearifan Lokal Nusantara. Yogyakarta: Kepel.

Senoaji, G. (2010). "Kearifan Lokal Masyarakat Baduy dalam Mengelola Hutan dan Lingkungannya". Majalah Humaniora. Volume 23, 1 Februari 2011 hal 14-25.

Somantri, R.A. (1988). Komunitas Adat Baduy. Bandung: Departemen Kebudayaan dan Pariwisata, Balai Pelestarian Sejarah dan Nilai Tradisional.

Suparmini, Setyawati, S., Sumunar, D.R.S. (2012). "Pelestarian Lingkungan 